\title{
Agronomic and nutritional characteristics of three buckwheat cultivars under organic farming in three environments of the Garfagnana mountain district
}

\author{
Lisetta Ghiselli, ${ }^{1}$ Remigio Tallarico, ${ }^{1}$ Marco Mariotti, ${ }^{2}$ Sigfrido Romagnoli, ${ }^{1}$ \\ Adriano P. Baglio, ${ }^{1}$ Pasquale Donnarumma, ${ }^{1}$ Stefano Benedettelli ${ }^{1}$ \\ ${ }^{1}$ Department of Agrifood Production and Environmental Sciences, University of Florence; \\ ${ }^{2}$ Department of Veterinary Science, University of Pisa, Italy
}

\begin{abstract}
Buckwheat is a crop that has virtually disappeared in Italy, and products are generally imported from Poland and China. Among the alternative crops, suitable for cultivation in marginal areas and mountain foothills, buckwheat is particularly adapted as it is a rustic crop that can be grown without chemical input. Buckwheat is rich in numerous functional components and is, therefore, suitable for the obtaining of health products. The aim of the present research was to evaluate the adaptability of three cultivars of buckwheat (Fagopyrum esculentum Moench) grown under organic management at different altitudes in the mountain district of Garfagnana (Tuscany, Italy). The main biometric and production parameters were measured. Protein, macroand microelement and total polyphenol contents were determined in the grain. Significant differences for most parameters were evident for the different environments; some biometric parameters were also different among cultivars. All genotypes were suitable for cultivation in
\end{abstract}

Correspondence: Lisetta Ghiselli, Department of Agrifood Production and Environmental Sciences, University of Florence, p.le delle Cascine 18, 50144 Firenze, Italy.

E-mail: lisetta.ghiselli@unifi.it

Key words: Buckwheat; organic agriculture; mineral elements.

Acknowledgements: the research was financed by the ARSIA-Regione Toscana and was supported by a grant from the Ente Cassa di Risparmio di Firenze, which contributed to the acquisition of a part of the instrumentation used for this work.

Conflict of interest: the authors declare no potential conflict of interest.

Conference presentation: SIA XLIV Congress, Bologna, 2015.

Received for publication: 30 December 2015.

Revision received: 24 March 2016.

Accepted for publication: 26 March 2016.

@C Copyright L. Ghiselli et al., 2016

Licensee PAGEPress, Italy

Italian Journal of Agronomy 2016; 11:729

doi:10.4081/ija.2016.729

This article is distributed under the terms of the Creative Commons Attribution Noncommercial License (by-nc 4.0) which permits any noncommercial use, distribution, and reproduction in any medium, provided the original author(s) and source are credited. the Garfagnana district based on yield and biometric data. Mineral element content was useful for the characterisation of geographic origin.

\section{Introduction}

Buckwheat is a crop that has practically disappeared in Italy. Commercialised products are imported almost entirely from Eastern Europe, particularly Poland, as well as from China. As a result, information relating to the production systems is often lacking. Today there is the need, especially in the marginal areas of mountains and foothills, to introduce alternative crops in crop cycles with already established species. Buckwheat is ideal for this purpose, being characterised as an easy-to-grow crop that can be cultivated without chemical input. Buckwheat grain may be eaten whole after decortication, or alternatively, the ground flour may be used either in the pure state or in mixtures with other grains for the production of bread, pasta (fresh or dried), biscuits and pastries.

In recent years, there has been an increasing interest in the consumption of products made from buckwheat flour. In particular, in the field of organic and functional foods, both consumers and processors are looking for products with properties that are beneficial to human health (Slavin, 2004; Giménez-Bastida et al., 2015). Buckwheat represents a crop containing numerous components with functional properties (Kreft et al., 2006; Zhang et al., 2012). The daily consumption of functional foods for important bioactive components is also effective in reducing the onset of chronic disease (Diplock et al., 1999; KrisEtherton et al., 2002; Sofi et al., 2010; Ghiselli et al., 2013).

Buckwheat, although not a grass, forms part of the category known as pseudocereals, in that the seeds used to make flour contain nutrients (proteins, fats and carbohydrates) in proportions comparable to those found in wheat, maize and barley. The high biological value of proteins make buckwheat of particular interest to vegetarian diets, as well as the absence of gluten makes it suitable for celiacs (AlvarezJubete et al., 2010; Saturni et al., 2010).

Buckwheat is also considered a rich source of both macro- [potassium $(\mathrm{K})$, calcium $(\mathrm{Ca})$, magnesium $(\mathrm{Mg})$ ] and microelements [iron (Fe), manganese (Mn), zinc ( $\mathrm{Zn})]$, which are more concentrated in the outer layers of the grain (Bonafaccia et al., 2003; Steadman et al., 2001b).

Buckwheat is also rich in phenolic compounds with antioxidant properties, in particular, the flavonoid rutin (Gabrovska et al., 2002; Kreft et $a l ., 2006)$. There are relatively few studies reporting the content of mineral elements and phenolic compounds in different buckwheat accessions and different environments. The aim of this research was to compare different varieties of buckwheat grown under organic conditions in different locations to evaluate differences in principal biometric data 
and production yields. Another purpose of this study was to evaluate the possibility to differentiate samples of buckwheat flour according to their geographical origin by means of chemical analysis and especially by their content in mineral elements, as already recognised in several works on many other plant species (Anderson and Smith, 2002; Ariyama et al., 2007; Di Giacomo et al., 2007).

\section{Materials and methods}

\section{Buckwheat samples and field experiments}

Three cultivars of buckwheat (Fagopyrum esculentum Moench), listed in Table 1, were compared at two locations in the mountain district of Garfagnana (Tuscany, Italy). The two locations were Sillano and Camporgiano, respectively. The trial in Sillano was conducted over two years (2008-2009), whereas that in Camporgiano was conducted in 2009 , thus obtaining three different testing environments. The geographical characteristics of Sillano were as follows: $44^{\circ} 15^{\prime} \mathrm{N}$ lat., $10^{\circ}$ 15' E long., $1200 \mathrm{~m}$ a.s.l., slope of $10-15 \%$ in SW direction, sandy soil rich in organic matter, poor gravel content. In 2008, weather data showed a summer drought with only $18.4,15.2$ and $35.2 \mathrm{~mm}$ of rain in July, August and September, respectively (Figure 1). Weather conditions were more favourable in 2009 (Figure 1) but always with a rainfall deficit in the months of July and August with 25.4 and $21.8 \mathrm{~mm}$, respectively. Similarly, characteristics for Camporgiano were as follows: $44^{\circ} 11^{\prime} \mathrm{N}$ lat., $10^{\circ} 17^{\prime} \mathrm{E}$ long., $480 \mathrm{~m}$ a.s.l., level ground facing NW direction, alluvial soil of medium texture poor in gravel. Weather data for 2009 showed a rainfall of 46.6 and $9.6 \mathrm{~mm}$, in the months of July and August, respectively (Figure 2).

The preceding crops in both years and locations consisted of grazing meadows. Sowing dates are provided in Table 1 . The varieties selected were sown in large plots of approximately $450 \mathrm{~m}^{2}(25 \times 18 \mathrm{~m})$. Organic cultivation techniques were adopted, with plowing to a depth of $20 \mathrm{~cm}$, followed by harrowing for the preparation of the seedbed. Given the limited cultivation requirements for this species, no fertiliser was applied during the crop cycle. On the basis of the extent of seed germination and the weight of 1000 seeds, each cultivar seed was sown in order to obtain an emergence of 200 plants $\mathrm{m}^{-2}$.

\section{Crop growth parameters}

Measurements of various morphological characters were carried out, on each plot, at various crop growth stages. These included: number of leaves per plant, measured at the flowering stage; plant height, number of branches per plant, first branch insertion height, and number of seed clusters per plant, measured at ripening. The harvest was carried out mechanically with combine harvesters on October 1, 2008 and October 9, 2009 in Sillano, and on September 30, 2009 in Camporgiano.

Immediately prior to harvest, a representative area of $1 \mathrm{~m}^{2}$ was cut by hand from each plot. The plants collected from these areas were, respectively, dried in an oven at $80^{\circ} \mathrm{C}$ for three days, and then threshed manually. From these samples the following determinations were made: the number and the total dry weight of the plants, the weight of the vegetative parts and the seed weight. Yield $\left(\mathrm{t} \mathrm{ha}^{-1}\right)$ was calculated from seed weight. From these data, the harvest index was also calculated from the ratio between grain weight and the total dry weight. A grain sample of $500 \mathrm{~g}$ was taken from each plot, and 1000 grain weight and test weight were determined.

The 1000 grain weight corresponds to the average value of three replicates of 100 seeds per plot. The test weight was determined by Schopper scales. The grain was then ground with a small stone mill for domestic use (21 Fidibus; Naturalia, Bolzano, Italy). The ground ach- enes were sieved with a $1.25 \mathrm{~mm}$ sieve to separate the shells and then with a $0.5 \mathrm{~mm}$ sieve to separate the bran and obtain the flour. The per cent yield in flour was then determined.

\section{Biochemical analyses}

Ash content, nitrogen $(\mathrm{N})$ and total protein, mineral elements and total polyphenols were determined on flour samples. Ash content [\% dry matter (DM)] was determined in three replicates for each sample after incineration in a muffle furnace at $550^{\circ} \mathrm{C}$, according to the official

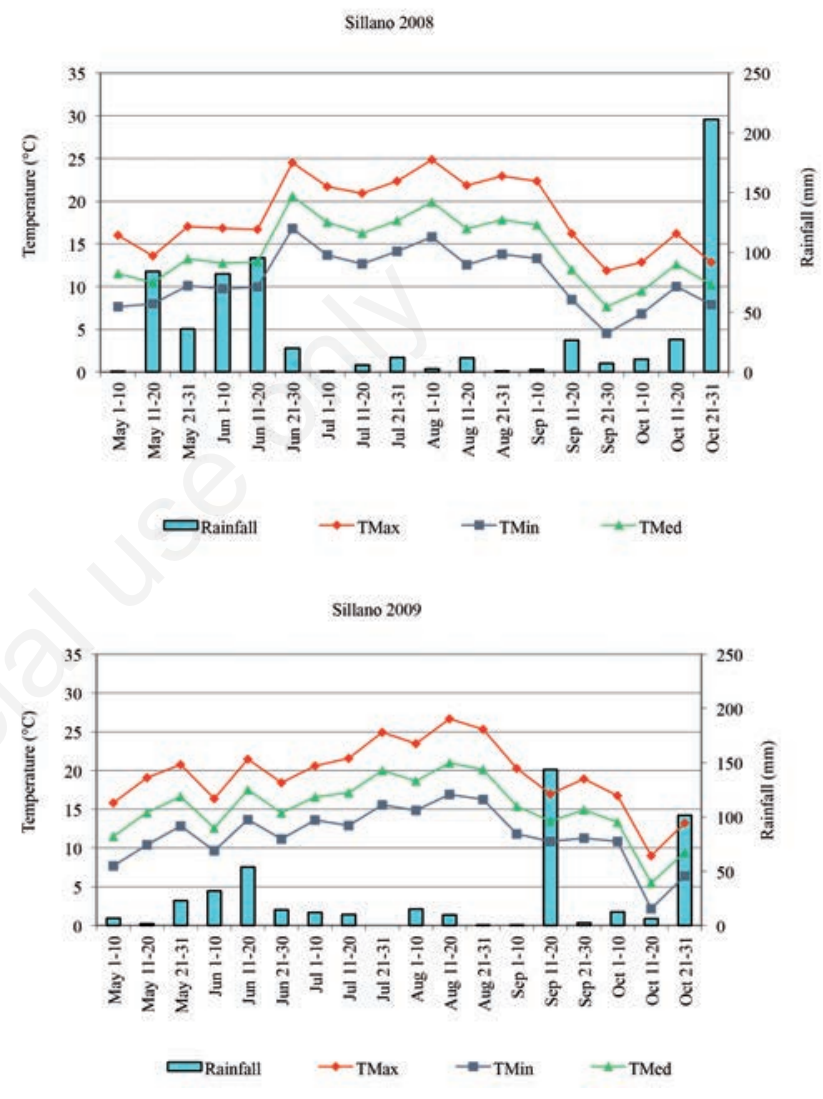

Figure 1. Meteorological trend during 2008 and 2009 growing seasons at Sillano (LU).

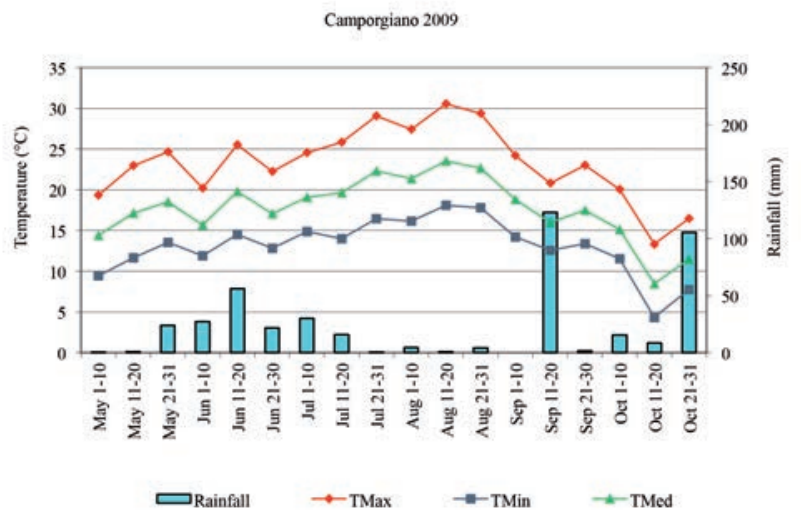

Figure 2. Meteorological trend during 2009 growing season at Camporgiano (LU). 
Association of Official Analytical Chemists (AOAC) method. N content was determined by the Flash Elemental Analyser CHN (Thermo Fisher Scientific, Waltham, MA, USA) using the Dumas method. Total protein (\% DM) was then calculated from the total $\mathrm{N} \times 5.70$ coefficient. The samples were analysed for micro- [copper $(\mathrm{Cu}), \mathrm{Fe}, \mathrm{Mn}, \mathrm{Zn}]$ and macronutrients [ $\mathrm{Ca}, \mathrm{K}, \mathrm{Mg}, \mathrm{Na}$, phosphorus (P)]. These elements were measured, being the most important from the point of view of human nutrition. Additional mineral elements [aluminium (Al), boron (B), barium (Ba), chromium (Cr), nickel (Ni), strontium ( $\mathrm{Sr}$ )] were measured to characterise products in terms of the geographical origin, as done in previous works on plant products (Padín et al., 2001; Ariyama et al., 2007; Di Giacomo et al., 2007). Flour samples were digested with $\mathrm{HNO}_{3}$ [0.5 $\mathrm{g}$ in $10 \mathrm{~mL}$ of 7:3 (v/v) ultra-pure $\mathrm{HNO}_{3} / \mathrm{Milli}-\mathrm{Q} \mathrm{H}_{2} \mathrm{O}$ ] in a microwave accelerated reaction system (Model MARS 6; CEM Corp., Matthews, NC, USA). Digestion conditions consisted of three ramps: $120^{\circ} \mathrm{C}(1 \mathrm{~min}), 170^{\circ} \mathrm{C}(1 \mathrm{~min})$ and $180^{\circ} \mathrm{C}(6 \mathrm{~min})$ in which 12,6 and 4 min were required to arrive at the respective maximum efficiency temperatures. After digestion, the samples were diluted to $25 \mathrm{~mL}$ with Milli- $Q$ water. The concentrations of mineral elements in the digested solution were measured by the ICP-AES spectrometer (inductively coupled plasma - atomic emission spectroscopy) IRIS Intrepid II XSP Radial (Thermo Fisher Scientific). Mineral element concentration was expressed on a dry weight basis and results were adjusted for blanks.

Total polyphenol content ( $\left.\mathrm{mg} \mathrm{kg}^{-1} \mathrm{DM}\right)$ was measured on aliquots of $10 \mathrm{~g}$ each, subject to hot extraction with a water/methanol mixture and further subjected to filtration and centrifugation. Extracts were analysed for the phenol quantification using the colorimetric procedure based on the Folin-Ciocalteau reagent and subsequent spectrophotometric reading at $760 \mathrm{~nm}$ (Singleton et al., 1999).

\section{Soil analyses}

Prior to the analysis of soil mineral elements, the $\mathrm{pH}$ in $\mathrm{H}_{2} \mathrm{O}$ was measured according to the Italian official methods of analysis for soil chemistry (Italian Regulation, 1999).

The exchangeable cations ( $\mathrm{Na}, \mathrm{K}, \mathrm{Mg}$ and $\mathrm{Ca}$, including $\mathrm{Sr}$ and $\mathrm{Ba}$ ), were detected by extraction with solution of ammonium acetate at $\mathrm{pH}$ 7. This type of extraction was also employed for non-metallic elements (B, P), for which the official methods were not suitable for ICP-AES analysis. The extraction solution was prepared by dissolving $77.08 \mathrm{~g}$ of ammonium acetate $\left(\mathrm{CH}_{3} \mathrm{COONH}_{4}\right)$ in deionised $\mathrm{H}_{2} \mathrm{O}$, then adjusting the $\mathrm{pH}$ to 7 with an aqueous solution of $\mathrm{NH}_{3}$ to a final volume of 1000 $\mathrm{mL}$. The availability in the soil of the remaining metallic elements (Al, $\mathrm{Cr}, \mathrm{Cu}, \mathrm{Fe}, \mathrm{Mn}, \mathrm{Ni}, \mathrm{Zn}$ ) was evaluated by extraction with ethylenediaminetetraacetic acid (EDTA) according to the Italian official methodology. The solutions obtained from the extraction with ammonium acetate and EDTA, respectively, were subsequently analysed using the ICP-AES spectrometer.

\section{Statistical analysis}

Data were subjected to analysis of variance (ANOVA) using SPSS (Statistical Package for Social Sciences Inc., Chicago, IL, USA) for Windows (version 20.0) to verify the significance of the sources of variation. In the case of significant values, the differences between the means were tested with the test of Bonferroni multiple comparisons. Environments (3 levels) were considered factors with random effects, the cultivars (3 levels) factors with fixed effects. Both environment and cultivar were considered in the interaction cultivar $\times$ environment $(\mathrm{CV}$ $\times$ Env) using a mixed model analysis of variance.

\section{Results}

The morphological and production parameters are presented in Table 2.

The density presented highly significant differences $(\mathrm{P}<0.01)$ only for $\mathrm{CV} \times$ Env interaction, for this parameter showed a marked difference observed in Sillano in 2008 and due to the high value of the variety Bamby.

The height of the plants was highly significant among the environments and varying from $92.3 \mathrm{~cm}$ to $133.6 \mathrm{~cm}$. The $\mathrm{CV} \times$ Env interaction was highly significant, in fact, the variety Spacinska showed a trend very different: it was the tallest in Sillano in 2008, the shortest in Sillano 2009 and similar to others in the fields of Camporgiano 2009.

The number of leaves per plant showed highly significant differences only among the environments, with the value of Camporgiano 2009 higher than that of Sillano 2009, and the latter greater than that of Sillano 2008.

The number of branches per plant was significant $(\mathrm{P}<0.05)$ among environments, with maximum value in Sillano 2008, intermediate in Camporgiano 2009 and minimum in Sillano 2009. Significant differences among cultivars were also noted, with Spacinska higher than Lileja, while Bamby was in an intermediate position.

The insertion height of the first branch did not show significant differences among environments, or among cultivars; significant was the interaction $\mathrm{CV} \times$ Env, due to a different behaviour of the variety Lileja.

The number of seed clusters per plant (floral branches with at least one mature achene) showed highly significant differences among environments, with the prevalence of Camporgiano 2009 on Sillano 2009, while Sillano 2008 was very lower than them. For this character, the variety Bamby was slightly higher than Spacinska and Lileja, but without significant differences. The yield was found highly significant among the environments with higher values in Sillano 2009, lower in Camporgiano 2009 and the lowest in Sillano 2008. Highly significant was the interaction $\mathrm{CV} \times$ Env: in this case the variety Bamby, which

Table 1. List of growth environments and buckwheat cultivars and information about the main phenological phases.

\begin{tabular}{|c|c|c|c|c|c|}
\hline Environment and cultivar & Origin & Sowing date & $\begin{array}{l}\text { Flowering start } \\
\text { Days from sowing }\end{array}$ & Maturation start & Harvest \\
\hline $\begin{array}{l}\text { Sillano } 2008 \\
\text { Sillano } 2009 \\
\text { Camporgiano } 2009\end{array}$ & & $\begin{array}{l}3 \text { July } \\
9 \text { June } \\
9 \text { June }\end{array}$ & $\begin{array}{l}32 \\
37 \\
31\end{array}$ & $\begin{array}{l}64 \\
63 \\
60\end{array}$ & $\begin{array}{c}90 \\
107 \\
113\end{array}$ \\
\hline $\begin{array}{l}\text { Bamby } \\
\text { Lileja } \\
\text { Spacinska }\end{array}$ & $\begin{array}{l}\text { Austria } \\
\text { Russia } \\
\text { Slovakia }\end{array}$ & & $\begin{array}{l}31 \\
34 \\
34\end{array}$ & $\begin{array}{l}60 \\
63 \\
64\end{array}$ & $\begin{array}{l}103 \\
103 \\
103\end{array}$ \\
\hline
\end{tabular}


was the most productive in 2009 in the location of Sillano, recorded the lowest value in Camporgiano.

The harvest index presented significant differences among environments, with Sillano 2009 higher than the other two environments. Highly significant was the interaction CV $\times$ Env, with the lowest values for Spacinska in Sillano 2008 and for Bamby in the other environments.

The 1000 grain weight showed highly significant differences among environments, with Sillano 2009 clearly prevailing on Camporgiano 2009 and Sillano 2008. Among varieties Lileja preceded Spacinska, then there was the variety Bamby. The interaction $\mathrm{CV} \times$ Env was highly significant. The observed trend of the three varieties in the two years in Sillano was almost similar, while there was a greater reduction in Camporgiano 2009 for the variety Bamby than the other two. The test weight was highly significantly higher in Sillano, where in 2008 and 2009 there were values not significantly different, but higher than those of Camporgiano 2009. Even among varieties differences were significant: Bamby was much higher, while Spacinska and Lileja were similar to each other. The interaction $\mathrm{CV} \times$ Env was also highly significant in this case. The significance of the interaction was mainly due to the drastic reduction in test weight of Bamby cultivar when grown in Camporgiano.

With respect to the yield of flour, only the $\mathrm{CV} \times$ Env interaction was highly significant: the variety Bamby showed greater stability, while Lileja and Spacinska showed opposite trends.
In Table 3 the nutritional components (protein, ash, total phenols, macroelements) content of buckwheat flour samples is indicated.

The proteins were more abundant in Camporgiano 2009, intermediate in Sillano 2009 and the lowest in Sillano 2008.

The ash content showed highly significant differences among environments, with higher values for Camporgiano 2009 compared to Sillano 2008, and even more different from Sillano 2009. Among the cultivars there were not significant differences, while highly significant was the interaction CV $\times$ Env, with the lowest values for Lileja in Sillano 2009 and for Spacinska in Sillano 2008 and Camporgiano 2009.

The differences among environments were highly significant for the content in total polyphenols, with the values found in Camporgiano 2009 and Sillano 2009 almost equal to each other but higher than Sillano 2008. The CV $\times$ Env interaction was significant with the variety Bamby, which presented a lower polyphenol content in Sillano in both years of the study, and the highest concentration when grown in Camporgiano.

The calcium content was higher in Sillano 2008 than in Camporgiano 2009 and Sillano 2009; among cultivars, the content of Bamby for this element was higher than those of Lileja and Spacinska. The $\mathrm{CV} \times$ Env interaction was highly significant, with greater variability of the variety Bamby.

The potassium content showed highly significant differences among environments, with Camporgiano 2009 preceding Sillano 2008 and

Table 2. Morphological and productive parameters detected in different environments and cultivars.

\begin{tabular}{|c|c|c|c|c|c|c|c|c|c|c|c|}
\hline $\begin{array}{l}\text { Environment } \\
\text { and cultivar }\end{array}$ & $\begin{array}{l}\text { Density } \\
\text { n plants } \\
\text { m }^{-2}\end{array}$ & $\begin{array}{l}\text { Plant } \\
\text { height } \\
\mathrm{cm}\end{array}$ & $\begin{array}{l}\text { Leaves/ } \\
\text { plant } \\
\text { n }\end{array}$ & $\begin{array}{c}\text { Branches/ } \\
\text { plant } \\
\text { n }\end{array}$ & $\begin{array}{l}\text { 1st branch } \\
\text { insertion } \\
\text { height } \\
\mathrm{cm}\end{array}$ & $\begin{array}{c}\text { Seed } \\
\text { clusters/ } \\
\text { plant } \\
\text { n }\end{array}$ & $\begin{array}{l}\text { Yield } \\
\text { t ha-1 }\end{array}$ & $\begin{array}{c}\text { Harvest } \\
\text { index }\end{array}$ & $\begin{array}{l}1000 \text { grain } \\
\text { weight } \\
\text { g }\end{array}$ & $\begin{array}{l}\text { Test } \\
\text { weight } \\
\mathrm{kg} \mathrm{hL}^{-1}\end{array}$ & $\begin{array}{l}\text { Yield } \\
\text { of flour } \\
\%\end{array}$ \\
\hline $\begin{array}{l}\text { Sillano } 2008 \\
\text { Sillano } 2009 \\
\text { Camp. } 2009\end{array}$ & $\begin{array}{l}156.0 \\
181.0 \\
170.9\end{array}$ & $\begin{array}{c}92.27^{\mathrm{b}} \\
98.30^{\mathrm{b}} \\
133.64^{\mathrm{a}}\end{array}$ & $\begin{array}{l}15.60^{\mathrm{c}} \\
28.10^{\mathrm{b}} \\
42.51^{\mathrm{a}}\end{array}$ & $\begin{array}{l}7.57^{\mathrm{a}} \\
2.87^{\mathrm{c}} \\
3.93^{\mathrm{b}}\end{array}$ & $\begin{array}{l}19.47 \\
22.23 \\
19.69\end{array}$ & $\begin{array}{l}14.00^{\mathrm{c}} \\
23.07^{\mathrm{b}} \\
42.02^{\mathrm{a}}\end{array}$ & $\begin{array}{l}1.21^{\mathrm{c}} \\
2.28^{\mathrm{a}} \\
2.02^{\mathrm{b}}\end{array}$ & $\begin{array}{l}0.354^{\mathrm{c}} \\
0.486^{\mathrm{a}} \\
0.387^{\mathrm{b}}\end{array}$ & $\begin{array}{l}20.93^{\mathrm{b}} \\
23.33^{\mathrm{a}} \\
21.18^{\mathrm{b}}\end{array}$ & $\begin{array}{l}62.55^{\mathrm{a}} \\
63.78^{\mathrm{a}} \\
61.01^{\mathrm{b}}\end{array}$ & $\begin{array}{l}74.12 \\
74.41 \\
73.86\end{array}$ \\
\hline $\begin{array}{l}\text { Bamby } \\
\text { Lileja } \\
\text { Spacinska }\end{array}$ & $\begin{array}{l}199.3 \\
153.0 \\
155.6\end{array}$ & $\begin{array}{l}106.13 \\
104.02 \\
114.06\end{array}$ & $\begin{array}{l}31.00 \\
24.93 \\
30.28\end{array}$ & $\begin{array}{l}4.90^{\mathrm{ab}} \\
4.38^{\mathrm{b}} \\
5.09^{\mathrm{a}}\end{array}$ & $\begin{array}{l}15.92 \\
23.56 \\
21.91\end{array}$ & $\begin{array}{l}28.14 \\
24.16 \\
26.79\end{array}$ & $\begin{array}{l}1.77 \\
1.99 \\
1.76\end{array}$ & $\begin{array}{l}0.372 \\
0.447 \\
0.407\end{array}$ & $\begin{array}{l}19.44^{c} \\
23.69^{a} \\
22.32^{b}\end{array}$ & $\begin{array}{l}65.21^{\mathrm{a}} \\
60.99^{\mathrm{b}} \\
61.14^{\mathrm{b}}\end{array}$ & $\begin{array}{l}74.98 \\
72.98 \\
74.43\end{array}$ \\
\hline Env & $\mathrm{ns}$ & $* *$ & $* *$ & $* *$ & ns & $* *$ & $* *$ & $* *$ & $* *$ & $* *$ & $\mathrm{~ns}$ \\
\hline $\mathrm{CV}$ & ns & ns & ns & $*$ & ns & ns & ns & ns & $*$ & $*$ & ns \\
\hline $\mathrm{CV} \times \mathrm{Env}$ & $* *$ & $* *$ & $\mathrm{~ns}$ & ns & $*$ & $\mathrm{~ns}$ & $* *$ & $* *$ & $* *$ & $* *$ & $* *$ \\
\hline
\end{tabular}

ns, not significant. ${ }^{\text {a-c }}$ Different letters indicate values significantly different at $\mathrm{P}<0.05\left({ }^{*}\right)$ or $\mathrm{P}<0.01\left(^{* *}\right)$ among environments or among cultivars.

Table 3. Total protein content, ash, phenolic compounds and macro elements detected on flour samples from the different environments and cultivars.

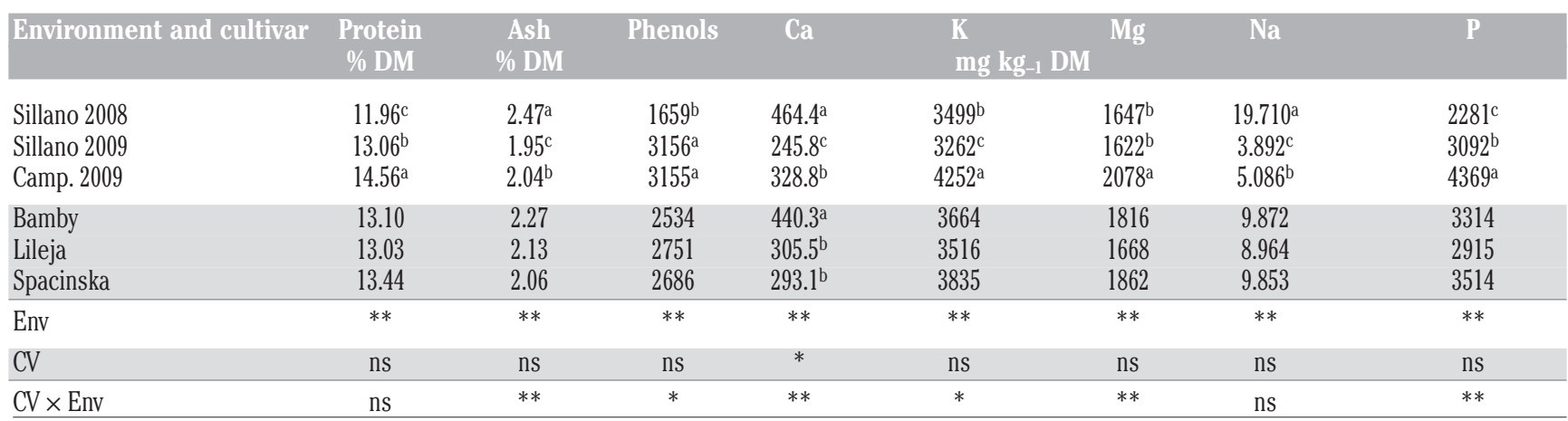

Ca, calcium; K, potassium; Mg, magnesium; Na, sodium; P, phosphorus; DM, dry matter. ns, not significant. a-cDifferent letters indicate values significantly different at $\mathrm{P}<0.05\left({ }^{*}\right)$ or $\mathrm{P}<0.01\left({ }^{* *}\right)$ among environments or among cultivars. 
Sillano 2009. The interaction CV $\times$ Env was significant, with the variety Lileja that was in Sillano 2009 the variety with the highest value, and in Camporgiano 2009 was the one with the lowest value.

Magnesium was more abundant in Camporgiano 2009 compared to Sillano 2008 and Sillano 2009. In this case, the interaction CV $\times$ Env was highly significant, with the variety Spacinska that showed the greatest variability of behaviour in the different environments.

The sodium was more abundant in Sillano 2008 than in Camporgiano 2009 and Sillano 2009, but did not show significant differences among cultivars.

Phosphorus was higher in Camporgiano 2009 compared to Sillano 2009 and Sillano 2008; CV × Env interaction was highly significant. The variety Spacinska showed the highest concentration in Sillano in both years, and recorded one of the lowest values in Camporgiano.

Table 4 shows the microelement content on flour samples.

Aluminium was significantly different between environments, with higher content in Sillano 2008 followed by Sillano 2009 and Camporgiano 2009. Interaction CV $\times$ Env proved highly significant, with the highest values for Spacinska in Sillano 2008 and Sillano 2009, and the lowest for the same variety in Camporgiano 2009.

Boron proved more abundant in Sillano 2008, followed respectively by Camporgiano 2009 and Sillano 2009, while among cultivars was more abundant in Bamby, followed by Lileja and Spacinska.

The barium content was higher in Sillano 2008 followed by Sillano 2009 and Camporgiano 2009. In this case, interaction CV $\times$ Env was also highly significant, with maximum values for Lileja in Sillano 2008, and for Bamby in Sillano 2009 and Camporgiano 2009.

Chromium presented only a significant CV $\times$ Env interaction, with the variety Bamby which recorded the lowest value when cultivated in Sillano 2008, and the highest value in Camporgiano 2009.

Copper showed highly significant differences among varieties only, with a higher content in Bamby, followed by Lileja and Spacinska.

Iron showed highly significant differences among environments and was more present in Sillano 2008 compared to Camporgiano 2009 and Sillano 2009. Highly significant was the interaction environment-cultivar: the variety Spacinska showed the highest content in Sillano in both years; instead it showed the lowest value, alongside the variety Lileja, in Camporgiano.

Manganese was more abundant in Sillano 2008 compared to Sillano 2009 and Camporgiano 2009. The CV $\times$ Env interaction was highly significant. Indeed Lileja showed values relatively higher when grown in Sillano 2008 and lower when grown in Camporgiano.

Nickel showed high significance of the differences among environments, with Sillano 2008 prevailing on Camporgiano 2009 and Sillano 2009; interaction CV $\times$ Env was also highly significant, with greater variability in cultivar Lileja.
Strontium was found in higher concentration in Sillano 2008 compared to Sillano 2009 and Camporgiano 2009, while among cultivars was more present in Bamby than in Lileja and Spacinska.

For zinc, only the interaction $\mathrm{CV} \times$ Env was highly significant. This result was mainly due to the variety Spacinska, which recorded the lowest values in Sillano in the two years, and the highest in Camporgiano 2009.

The analysis of the available fraction of mineral elements in the soil held in 2009 (Table 5) showed significant differences for macroelements $\mathrm{Na}$ and $\mathrm{P}$ and for micronutrients $\mathrm{B}, \mathrm{Cu}$ and $\mathrm{Zn}$; for all other elements measured, the differences were highly significant. The chemical composition of the soil was therefore very different between the two locations.

\section{Discussion}

The morphological parameters measured on buckwheat crops conducted in the three environments of the study provided very interesting results that should be considered along with the weather conditions that occurred during the trial.

With regard to the height of the plants, the lower value measured in Sillano 2008 and Sillano 2009 was probably due to the lower temperatures found in the location of Sillano and to the greater permeability and slope of the soil, which led to a faster draining and therefore to less available water; however, the development in height was found to be sufficient to ensure an adequate production. A similar trend was observed for the number of leaves per plant; in this case a significantly lower value was recorded in Sillano 2008, most likely due to the seasonal drought.

The number of branch stages per plant was higher in Sillano 2008, probably due to the lower density of the plants, which favoured the emission of lateral branches. In 2009, the number of stages was higher in Camporgiano, in agreement with the greater plant growth.

The insertion height of the first branch was always quite high (around $20 \mathrm{~cm}$ ), thus not creating problems in the mechanical harvest. The number of seed clusters per plant showed the same trend found for the leaves, in accordance with the different vegetative development and the different weather patterns. Very similar was the production per hectare, which was modest in Sillano 2008, but acceptable considering the seasonal drought; it was satisfactory in Camporgiano 2009 and even more in Sillano 2009, where the higher fruit set, helped by lower summer temperatures, more than offset the lower number of seed clusters. The yields substantially confirmed those already found by the authors in previous experiments in the same area (Tallarico et al., 2008, 2009). For

Table 4. Microelements detected on flour samples from the different environments and cultivars.

\begin{tabular}{|c|c|c|c|c|c|c|c|c|c|c|}
\hline Environment and cultivar & Al & B & $\mathrm{Ba}$ & $\mathrm{Cr}$ & $\mathrm{Cu}$ & $\begin{array}{c}\mathrm{Fe} \\
\mathrm{mg} \mathrm{kg-1} \mathrm{DM}\end{array}$ & $\mathrm{Mn}$ & $\mathbf{N i}$ & Sr & $\mathrm{Zn}$ \\
\hline Sillano 2008 & $74.59^{\mathrm{a}}$ & $8.980^{\mathrm{a}}$ & $1.533^{\mathrm{a}}$ & 0.171 & 5.618 & $74.22^{\mathrm{a}}$ & $22.84^{\mathrm{a}}$ & $4.516^{\mathrm{a}}$ & $1.318^{\mathrm{a}}$ & 29.24 \\
\hline Sillano 2009 & $60.37^{\mathrm{ab}}$ & $7.259^{b}$ & $0.757^{\mathrm{b}}$ & 0.203 & 5.755 & $40.85^{b}$ & $17.67^{\mathrm{b}}$ & $3.197^{\mathrm{b}}$ & $0.607^{\mathrm{b}}$ & 29.23 \\
\hline Camp. 2009 & $41.46^{\mathrm{b}}$ & $7.222^{\mathrm{b}}$ & $0.263^{c}$ & 0.276 & 5.575 & $37.34^{b}$ & $13.68^{b}$ & $0.682^{b}$ & $0.512^{\mathrm{b}}$ & 29.29 \\
\hline Bamby & 55.66 & $8.429^{a}$ & 0.931 & 0.198 & $6.133^{\mathrm{a}}$ & 50.08 & 19.06 & 2.985 & $1.011^{\mathrm{a}}$ & 29.94 \\
\hline Lileja & 43.27 & $7.666^{\mathrm{b}}$ & 1.018 & 0.170 & $5.578^{b}$ & 40.05 & 18.08 & 3.366 & $0.763^{b}$ & 28.85 \\
\hline Spacinska & 77.5 & $7.367^{\mathrm{b}}$ & 0.605 & 0.281 & $5.237^{\mathrm{b}}$ & 62.28 & 17.05 & 2.044 & $0.664^{b}$ & 28.97 \\
\hline Env & $* *$ & $* *$ & $* *$ & ns & ns & $* *$ & $* *$ & $* *$ & $* *$ & ns \\
\hline CV & ns & $* *$ & ns & ns & $* *$ & ns & ns & ns & $* *$ & ns \\
\hline $\mathrm{CV} \times \mathrm{Env}$ & $* *$ & ns & $* *$ & $*$ & ns & $* *$ & $* *$ & $* *$ & ns & $* *$ \\
\hline
\end{tabular}

Al, aluminium; B, boron; Ba, barium; Cr, chromium; Cu, copper; Fe, iron; Mn, manganese; Ni, nickel; Sr, strontium; Zn, zinc; DM, dry matter. ns, not significant. a-cDifferent letters indicate values significantly different at $\mathrm{P}<0.05(*)$ or $\mathrm{P}<0.01(* *)$ among environments or among cultivars. 
comparison, yields obtained in similar conditions in Italy and in nearby Slovenia were $1.15 \div 1.43$ t/ha (Baldassi, 1998), 1.75 t/ha (Bavec et al., 2002), $0.76 \div 1.53$ tha (Brunori et al., 2005).

In accordance with the yield was also the harvest index, significantly higher in Sillano 2009 where there was the maximum formation of achenes, even in the presence of a limited vegetative growth, thanks to the better environmental conditions.

Regarding the quality parameters of the grain, test weight presented the highest values in Sillano 2009 and values slightly lower, but statistically similar, in Sillano 2008, demonstrating the greater suitability of this location to buckwheat; the value was lower in Camporgiano, indicating a lower grain filling due to higher summer temperatures. The 1000 grain weight reached the maximum values in Sillano 2009, confirming the best conditions registered in this environment. Among the varieties, Bamby proved to have the lowest 1000 grain weight, but also the greatest test weight; the apparent contradiction was due to the different shape of achenes, rounder and with smaller wings than those of the other two varieties. Lileja was the cultivar with greater 1000 grain weight and lower test weight. Spacinska showed a 1000 grain weight similar to Lileja and an intermediate test weight; the shape of the achenes of these two varieties was also similar.

Chemical analysis carried out on the flour showed values in good accordance with those obtained in previous works (Steadman et al., 2001a, 2001b); the protein content was quite high, especially in the year 2009. The ash content was higher in Sillano 2008, probably because of the lower production, which enabled a higher concentration in mineral elements; phenolic compounds were more abundant in 2009. However, differences among varieties for protein content, ash, and phenols were not significant.

The content of mineral elements in the flour showed significant differences among environments for all elements considered, except $\mathrm{Cr}$ and $\mathrm{Cu}$. Limiting the comparison to the year 2009 to obtain a greater

Table 5. Chemical analysis of the soil samples of the two locations for the year 2009.

\begin{tabular}{|c|c|c|c|}
\hline Elements & Camporgiano & Sillano & $\mathbf{P}$ \\
\hline $\mathrm{pH}\left(\mathrm{H}_{2} \mathrm{O}\right)$ & 5.82 & 5.06 & - \\
\hline $\mathrm{C} \%$ & 1.901 & 4.032 & $* *$ \\
\hline $\mathrm{N} \%$ & 0.189 & 0.391 & $* *$ \\
\hline $\mathrm{Ca} \mathrm{mg} \mathrm{kg}^{-1}$ & 3525.333 & 503.900 & ** \\
\hline $\mathrm{K} \mathrm{mg} \mathrm{kg}^{-1}$ & 415.867 & 175.800 & ** \\
\hline $\mathrm{Mg} \mathrm{mg} \mathrm{kg}^{-1}$ & 399.733 & 67.850 & ** \\
\hline $\mathrm{Na} \mathrm{mg} \mathrm{kg-1}$ & 21.447 & 10.812 & * \\
\hline P mg kg-1 & 2.801 & 4.348 & $*$ \\
\hline $\mathrm{Al} \mathrm{mg} \mathrm{kg}{ }^{-1}$ & 345.533 & 853.300 & $* *$ \\
\hline $\mathrm{B} \mathrm{mg} \mathrm{kg}{ }^{-1}$ & 0.309 & 0.224 & $*$ \\
\hline Ba mg kg-1 & 21.643 & 20.203 & $* *$ \\
\hline Cr mg kg ${ }^{-1}$ & 0.529 & 0.724 & $* *$ \\
\hline $\mathrm{Cu} \mathrm{mg} \mathrm{kg}^{-1}$ & 10.988 & 7.179 & $*$ \\
\hline Fe mg kg-1 & 194.433 & 153.300 & $* *$ \\
\hline Mn mg kg-1 & 179.667 & 56.167 & $* *$ \\
\hline Ni mg kg-1 & 0.423 & 1.263 & $* *$ \\
\hline Sr mg kg-1 & 12.550 & 2.723 & $* *$ \\
\hline Zn mg kg-1 & 2.375 & 3.656 & $*$ \\
\hline
\end{tabular}

C, carbon; N, nitrogen; Ca, calcium; K, potassium; Mg, magnesium; $\mathrm{Na}$, sodium; $\mathrm{P}$, phosphorus; $\mathrm{Al}$, aluminium; B, boron; Ba, barium; Cr, chromium; Cu, copper; Fe, iron; Mn, manganese; Ni, nickel; Sr, strontium; Zn, zinc. ${ }^{*} \mathrm{P}<0.05 ;{ }^{*} \mathrm{P}<0.01$ homogeneity of data, the highest values were observed in Camporgiano 2009 for all macroelements (Ca, K, Mg, Na, P), whereas some trace elements $(\mathrm{Ba}, \mathrm{Mn}, \mathrm{Ni})$ were more abundant in Sillano 2009; other microelements ( $\mathrm{Al}, \mathrm{B}, \mathrm{Cr}, \mathrm{Cu}, \mathrm{Fe}, \mathrm{Sr}, \mathrm{Zn}$ ) showed no significant differences in 2009, but many of them (Al, B, Fe, Sr) were more abundant in Sillano 2008. The greater presence of macroelements in Camporgiano 2009 is in agreement with the higher availability of these elements in the soil of this location (Table 5), with the exception of $\mathrm{P}$, which was more easily available in Sillano. In the case of phosphorus, its reduced presence in the flours obtained in Sillano may be due to a more difficult absorption of the element in the presence of $\mathrm{Fe}^{3+}$ and $\mathrm{Al}^{3+}$ (generally more abundant in Sillano) with low soil pH (an average value of 5.06 was measured, against the 5.82 recorded in Camporgiano).

In respect to the trace elements, in all cases in which differences were found among the environments, Sillano gave higher values in flours: this was in agreement with the contents of the soil in some cases (Al, Ni) but not in others (B, Ba, Fe, Mn, Sr). Often, however, in vegetable products it was observed a greater absorption of trace elements, especially metal ones, with low $\mathrm{pH}$ conditions of the soil, independently from their concentration, as already noted by some of the authors in other works (Manzelli et al., 2010).

As for the varieties, significant differences were observed for only a few elements: in these cases ( $\mathrm{Ca}, \mathrm{B}, \mathrm{Cu}, \mathrm{Sr})$ the highest content in minerals was always detected in the flours obtained from the variety Bamby. This could be explained by a higher concentration of these elements in the smaller achenes characteristic of this cultivar. In general, the trend observed in studies on other plant species (Ariyama et al., 2007; Manzelli et al., 2010) was confirmed, indicating a higher influence of the environment, with respect to genotype, on the mineral content.

\section{Conclusions}

The study substantially proved, from an agronomic point of view, the good adaptation of all tested cultivars of buckwheat to the climate and the soil of Garfagnana. In fact, plant growth and yields were satisfactory in all environments; the main limiting factor was found to be the summer drought, typical of the climate of peninsular Italy. The study demonstrated also the greater suitability of the location situated at higher elevation (Sillano).

Other characteristics that for many other crops are limiting factors, such as the acidity of the soil, its low content in various mineral elements (in particular P), and the shortness of the growing season, did not cause growth problems to the plants. In fact, buckwheat takes advantage of poor soils, both for a lower risk of lodging, and for a lower vegetative development that, in case of drought, usefully reduces transpiration. It can be concluded that buckwheat is a crop suitable for the mountain environments of central Italy, where the cereals traditionally grown, both autumn-winter (such as emmer wheat) and summer ones (such as corn), are often affected by the limiting factors previously mentioned. Buckwheat is therefore a species of considerable interest to diversify cropping systems in these environments.

Chemical analyses of the buckwheat obtained in Garfagnana confirmed the excellent nutritional qualities of this pseudocereal, such as the content in proteins of good biological value, in minerals (especially magnesium and trace elements such as iron, copper, zinc, manganese) and in polyphenols.

The differences in mineral content were higher among the environments than among the cultivars. Therefore, this study demonstrated the importance of the mineral element analysis as a possible means of confirmation of the geographic origin of buckwheat. This is of potential interest for this crop, for which it would be beneficial to establish pro- 
ductions linked to their geographical origin. In this way better remuneration for producers could be ensured, and consumers could get a guarantee of high nutritional quality and wholesomeness of a product obtained in suitable and pristine environments, and cultivated with low-input techniques (integrated and organic agriculture). This applies particularly to Italy, where the production is currently negligible, and buckwheat is often imported from non-European countries that do not provide sufficient guarantees on the cultivation techniques utilised and on the correct use of pesticides.

\section{References}

Alvarez-Jubete L, Arendt EK, Gallagher E, 2010. Nutritive value of pseudocereals and their increasing use as functional gluten-free ingredients. Trends Food Sci. Tech. 21:106-13.

Anderson KA, Smith BW, 2002. Chemical profiling to differentiate geographic growing origins of coffee. J. Agr. Food Chem. 50:2068-75.

Ariyama K, Aoyama Y, Mochizuki A, Homura Y, Kadokura M, Yasui A, 2007. Determination of the geographic origin of onions between three main production areas in Japan and other countries by mineral composition. J. Agr. Food Chem. 55:347-54.

Baldassi A, 1998. Grano saraceno: interesse per una coltura dimenticata. Quaderni della Regione Piemonte. 12. Available from: http://www.regione.piemonte.it/archivio/agri/qrp/ita/news/pubblic/quaderni/num12/art18-12.htm

Bavec F, Pusnik S, Rajcan I, 2002. Yield performance of two buckwheat genotypes grown as a full-season and stubble-crop. Rost. Vyroba 48:351-5.

Bonafaccia G, Gambelli L, Fabjan N, Kreft I, 2003. Trace elements in flour and bran from common and tartary buckwheat. Food Chem. 83:1-5.

Brunori A, Brunori A, Baviello G, Marconi E, Colonna M, Ricci M, 2005. The yield of five buckwheat (Fagopyrum esculentum Moench) varieties grown in Central and Southern Italy. Fagopyrum 22:98-102.

Di Giacomo F, Del Signore A, Giaccio M, 2007. Determining the geographic origin of potatoes using mineral and trace element. J. Agr. Food Chem. 55:860-6.

Diplock AT, Aggett PJ, Ashwell M, Bornet F, Fern EB, Roberfroid MB, 1999. Scientific concepts of functional foods in Europe: consensus document. Br. J. Nutr. 81:1-28.

Gabrovska D, Fiedlerova V, Holasova M, Maskova E, Smrcinov H, Rysova J, Winterova R, Michalova A, Hutar M, 2002. The nutritional evaluation of underutilized cereals and buckwheat. Food Nutr. Bull. 23:246-9.

Ghiselli L, Sofi F, Whittaker A, Gori AM, Casini A, Abbate R, Gensini GF, Dinelli G, Marotti I, Benedettelli S, 2013. Effect of pasta consump- tion obtained by an old Italian durum wheat variety on cardiovascular parameters: an intervention study. Progr. Nutr. 15:265-73.

Giménez-Bastida JA, Piskula M, Zieliński H, 2015. Recent advances in development of gluten-free buckwheat products. Trends Food Sci. Technol. 44:58-65.

Italian Regulation, 1999. Ministero delle Politiche Agricole e Forestali: decreto ministeriale 13 settembre 1999. Approvazione dei Metodi ufficiali di analisi chimica del suolo. In: G.U. no. 248, 21/10/1999, Suppl. Ord. no. 185.

Kreft I, Fabjan N, Yasumoto K, 2006. Rutin content in buckwheat (Fagopyrum esculentum Moench) food materials and products. Food Chem. 98:508-12.

Kris-Etherton PM, Hecker KD, Bonanome A, Coval SM, Binkoski AE, Hilpert KF, Griel AE, Etherton TD, 2002. Bioactive compounds in foods: their role in the prevention of cardiovascular disease and cancer. Am. J. Med. 113:71-88.

Manzelli M, Romagnoli S, Ghiselli L, Benedettelli S, Palchetti E, Andrenelli L, Vecchio V, 2010. Typicity in potato: characterization of geographic origin. Ital. J. Agron. 5:61-7.

Padín PM, Peña RM, García S, Iglesias R, Barro S, Herrero C, 2001. Characterization of Galician (N.W. Spain) quality brand potatoes: a comparison study of several pattern recognition techniques. Analyst 126:97-103.

Saturni L, Ferretti G, Bacchetti T, 2010. The gluten-free diet: safety and nutritional quality. Nutrients 2:16-34.

Singleton VL, Orthofer R, Lamuela-Raventós RM, 1999. Analysis of total phenols and other oxidation substrates and antioxidants by means of Folin-Ciocalteu reagent. Method. Enzymol. 299:152-78.

Slavin J, 2004. Whole grains and human health. Nutr. Res. Rev. 17:99-110.

Sofi F, Ghiselli L, Cesari F, Gori AM, Mannini L, Casini A, Vazzana C, Vecchio V, Gensini GF, Abbate R, Benedettelli S, 2010. Effects of short-term consumption of bread obtained by an old Italian grain variety on lipid, inflammatory and haemorheological variables: an intervention study. J. Med. Food 13:1-6.

Steadman KJ, Burgoon MS, Lewis BA, Edwardson SE, Obendorf RL, 2001a. Buckwheat seed milling fractions: description, macronutrient composition and dietary fibre. J. Cereal Sci. 33:271-8.

Steadman KJ, Burgoon MS, Lewis BA, Edwardson SE, Obendorf RL, 2001b. Minerals, phytic acid, tannin and rutin in buckwheat seed milling fractions. J. Sci. Food Agric. 81:1094-100.

Tallarico R, Ghiselli L, Romagnoli S, Benedettelli S, 2008. Grano saraceno coltura dai molti usi. Inf. Agr. 35:45-6.

Tallarico R, Ghiselli L, Romagnoli S, Benedettelli S, Pardini A, 2009. Evaluation trials of two buckwheat cultivars in Apennine mountains (Central Italy). Fagopyrum 26:45-55.

Zhang ZL, Zhou ML, Tang Y, Li FL, Tang YX, Shao JR, Xue WT, Wu YM, 2012. Bioactive compounds in functional buckwheat food. Food Res. Int. 49:389-95. 